University of Nebraska - Lincoln

DigitalCommons@University of Nebraska - Lincoln

USDA Wildlife Services - Staff Publications

U.S. Department of Agriculture: Animal and

Plant Health Inspection Service

March 2001

\title{
PORCINE ZONA PELLUCIDA IMMUNOCONTRACEPTION: LONG- TERM HEALTH EFFECTS ON WHITE-TAILED DEER
}

\author{
Lowell A. Miller \\ National Wildlife Research Center \\ Ken Crane \\ National Wildlife Research Center \\ Stan Gaddis \\ National Wildlife Research Center \\ Gary J. Killian \\ Pennsylvania State University
}

Follow this and additional works at: https://digitalcommons.unl.edu/icwdm_usdanwrc

Part of the Environmental Sciences Commons

Miller, Lowell A.; Crane, Ken; Gaddis, Stan ; and Killian, Gary J., "PORCINE ZONA PELLUCIDA

IMMUNOCONTRACEPTION: LONG-TERM HEALTH EFFECTS ON WHITE-TAILED DEER" (2001). USDA

Wildlife Services - Staff Publications. 577.

https://digitalcommons.unl.edu/icwdm_usdanwrc/577

This Article is brought to you for free and open access by the U.S. Department of Agriculture: Animal and Plant Health Inspection Service at DigitalCommons@University of Nebraska - Lincoln. It has been accepted for inclusion in USDA Wildlife Services - Staff Publications by an authorized administrator of DigitalCommons@University of Nebraska - Lincoln. 


\title{
PORCINE ZONA PELLUCIDA IMMUNOCONTRACEPTION: LONG-TERM HEALTH EFFECTS ON WHITE-TAILED DEER
}

LOWELL A. MILLER, ${ }^{1}$ National Wildlife Research Center, 4101 LaPorte Avenue, Fort Collins, CO 80521, USA

KEN CRANE, National Wildlife Research Center, 4101 LaPorte Avenue, Fort Collins, CO 80521, USA

STAN GADDIS, National Wildlife Research Center, 4101 LaPorte Avenue, Fort Collins, CO 80521, USA

GARY J. KILLIAN, Almquist Research Center, Pennsylvania State University, University Park, PA 16802, USA

\begin{abstract}
As part of a 9-year study on the contraceptive effects of Porcine Zona Pellucida (PZP) on white-tailed deer (Odocoileus virginianus), we analyzed serum chemistry panels during the first 4 years. This included the first 2 years when does were being actively immunized, and 2 years post-immunization. The chemistry panel was designed to detect pathologies that might result from the immunization of the deer. Blood chemistry results did not suggest any pathological changes resulting from the immunization. Seasonal differences in serum cholesterol were similar in both the control and PZP-treated groups. Seasonal changes in the mean body weights of the treated and control groups reflected an increased weight of the control group in the spring, probably due to pregnancy. However, no statistical difference existed in the fall weights between the 2 groups throughout the 4-year study.
\end{abstract}

JOURNAL OF WILDLIFE MANAGEMENT 65(4):941-945

Key words: fertility control, health profile, immunocontraception, Odocoileus virginianus, porcine zona pellucida, PZP, white-tailed deer.

Overpopulation of certain wildlife species is recognized as a concern worldwide, although general disagreement exists on methods for dealing with this problem. Immunocontraception has been suggested as a viable alternative for limiting population growth in various species. Reduction of excess numbers of white-tailed deer that generate conflicts between humans and animals is a prime example of a situation where immunocontraception may become a valuable wildlife management tool.

Although contraception by inducing antibodies to PZP has been used in many species (Kirkpatrick et al. 1990, Turner et al. 1996, Miller et al. 1999), the long-term physiological effects of stimulating an immune response against an animal's own zona pellucida are largely unknown. It has been suggested that PZP immunization may cause ovarian dysgenesis (Mahi-Brown et al. 1988, Dunbar 1989, Tung et al. 1996) and loss of primordial follicles. Kirkpatrick et al. (1992) found that horses immunocontracepted with PZP for 3 consecutive years had abnormal ovarian function as shown by markedly depressed estrogen secretion. Miller et al. (1999) also observed that during the first 2 years of active PZP immunization, some deer did not cycle because of failure to increase progesterone during the fall breeding season. In the next breeding season after immunizations ceased, the rise in progesterone indicated that they

\footnotetext{
${ }^{1}$ E-mail: Lowell.A.Miller@USDA.gov
}

began to cycle. In both cases the deer remained infertile, apparently by 2 different mechanisms.

It also has been theorized that immunocontraception may select for immunocompromised, sick, and diseased animals by failing to render them sterile. Consequently, healthy animals with a good immune system would become immunocontracepted and favor selection of a less healthy population to continue to propagate the species (Nettles 1997).

The effects of immunocontraception on deer health are difficult to determine without longterm studies of treated individuals. Our study was undertaken as part of a 9-year contraceptive study. Antibody titers, hormone levels, and reproductive results have been reported previously (Miller et al. 1999). In this study, we assessed the effects of repeated PZP immunization on the health of female deer using a 22-test blood serum profile for treated and control animals over a 4 year period. The serum chemistry health profile was intended to evaluate the function of the major organs and physiological systems, such as the liver, kidney, heart, pancreas, immune system, and electrolyte balance.

Seasonal changes may influence the chemistry values in the deer. Deer living in temperate latitudes show seasonal fluctuations in reproduction, metabolism, appetite, growth, and pelage growth and molt. Changes in the length of the photoperiod have been shown to be the major environmental factor controlling seasonal cycles via the secretion of the hormone melatonin during 
the night. Estrus cycling and sexual behavior of deer are stimulated by shortening day length, as are increased food intake and deposition of fat in the autumn and early winter, which prepare the animal for cold weather and the increased energy needed for pregnancy and lactation. Seasonal restriction of breeding ensures that fawning and lactation coincide with periods of favorable weather and maximal food supply (Verne and Ullrey 1984, Lincoln 1992). These seasonal changes also are reflected in the blood chemistry of the deer (Tumbleson et al. 1968).

\section{METHODS}

Our study was part of a multiyear white-tailed deer infertility research project conducted on the deer herd at Pennsylvania State University (PSU), University Park, Pennsylvania, USA, in cooperation with National Wildlife Research Center (NWRC), Fort Collins, Colorado, USA. The fertility studies included 9 years of monitoring PZPcontracepted deer (Miller et al. 1999) and 5 years observing Gonadotropin-Releasing Hormone (GnRH)-contracepted deer (Miller et al. 2000). The female deer selected for this study were proven breeders, 3 to 4 years of age, weighing 53-66 kg. We fed the deer free choice of pellets prepared for the PSU deer herd and alfalfa hay. During handling, we sedated the deer with 0.5 to $1.0 \mathrm{ml}$ of xylazine per deer based on their weight and restrained in a squeeze chute built for deer.

We immunized 11 deer with purified PZP purchased from B. Dunbar (Baylor College of Medicine, Houston, Texas, USA). We injected each treated deer with $1 \mathrm{ml}$ of PZP vaccine distributed subcutaneously and intradermally among several sites above the vertebrae of the back between the scapulae. The $1 \mathrm{ml}$ prime dose (given in Sep) consisted of $0.5 \mathrm{ml}$ of saline containing $500 \mu \mathrm{g}$ of PZP emulsified with $0.5 \mathrm{ml}$ of complete Freund's adjuvant (CFA). Two boosters were given (1 in early Oct and 1 in late Oct), each containing 300 $\mu \mathrm{g}$ PZP in $0.5 \mathrm{ml}$ saline mixed with $0.5 \mathrm{ml}$ of incomplete Freund's adjuvant (IFA). Control deer were sham injected with saline emulsified 1:1 as above with CFA in the prime dose or IFA in each booster dose (Miller et al. 1999).

We immunized 8 PZP-treated deer the first year, and boosted them the second year. Three deer were boosted the third year.

We collected all blood samples between August and February of each year. Blood was taken prior to each prime and booster injection. Following clotting, samples were centrifuged and serum was harvested and stored at $-20^{\circ} \mathrm{C}$ for subsequent determinations of chemistry profiles. We weighed deer each time they were brought into the pens to be vaccinated, have blood samples taken, or to be monitored for pregnancy. Deer were fasted for approximately $12 \mathrm{hr}$ before collecting samples. We sent serum to LabCorp in Englewood, Colorado, USA, for chemistry profiles, which were determined on an Olympus AU5000. (Reference to individual laboratories or equipment does not imply endorsement by the U.S. government.) Each profile contained 22 individual chemistry tests, for a total of 3,322 tests used in the data presented.

During the 4 years of the study, does were exposed to 3 experienced bucks of proven fertility from the first week of November and through the end of March. One buck always became dominant and bred most of the does. To determine when the does were in estrus, behavioral observations of the bucks toward the treated does were made by PSU students 3 times daily from 7 November through 12 February and 2 times daily until 28 February. Behavioral activity by the buck was ranked as sniffing or pursuit of the female, aggressive guarding, and mounting and copulation. Fawning data were recorded for each doe and summarized by treatment.

We calculated $P$ values by ANOVA with $\alpha=0.05$. We calculated normal ranges of chemistry parameters using Mean $\pm 2 \mathrm{SD}$, which is an established practice in the clinical laboratory. We performed calculations using StatView (SAS Institute, Cary, North Carolina, USA).

\section{RESULTS \\ Estrous Behavior}

Most control deer $(n=36)$ bred and conceived at the first observed estrus each year. This occurred during November, soon after they were introduced to the bucks. Each control doe averaged 1.2 estrus events (range $1-2$ ), and breeding occurred over a period of 44 days. In contrast, the PZP-treated does averaged 3.6 sexual encounters per doe, and breeding occurred over a period of 98 days. Estrus was observed from November to as late as March. The dominant buck was involved in all of the early breeding; however, the dominant buck lost interest in February and March, allowing the subordinate bucks to be involved with the late estrous activity. The length of the breeding period differed between the 2 groups $(P<0.01)$. 


\section{Fawning}

The control group averaged $1.88 \pm 0.08$ fawns/doe (mean $\pm \mathrm{SE}$ ) over the 4-year period, while PZP-treated does averaged $0.25 \pm 0.14$ fawns/doe, an $87 \%$ reduction $(P<0.0001)$. During the first 2 years of this study, the deer were actively immunized. As shown in a previous paper (Miller et al. 1999), during the first 2 years, the deer apparently did not cycle or develop corpora lutea as indicated by the lack of progesterone increases. However, during years 3-4, the deer began to cycle as indicated by the rise in progesterone, suggesting that there may be 2 mechanisms involved in the induced infertility. During active immunization, the immune response may suppress or prevent the development of the corpora lutea. In later years, infertility may be induced by anti-PZP binding to the egg preventing sperm binding. These deer returned to fertility in the 5 years following this study, indicating that there was no permanent damage to the ovaries. As the deer returned to fertility, they usually gave birth to a single fawn 1 or more years.

We monitored PZP-treated deer in this study for 5 years beyond the initial 4-year study to determine the long-term effects of PZP treatment on health and fertility. As the health profiles suggest, no adverse long-term health effects or decreased longevity have been observed for the treated deer. All deer have survived 5 more years after this 4-year study, and all but 1 PZP-immunized deer has returned to fertility. The length of time that each deer remained infertile varied from 4 to 9 years. Most deer had 1 fawn the first year they returned to a fertile condition. In succeeding years they returned to having twins. This pattern suggests a partial contraceptive protection as the antibody titers begin to drop. The overall fertility reduction throughout the 9 years was $72 \%$.

\section{Antibody Titers}

As shown in our previous paper (Miller et al. 1999), all 8 deer responded to native PZP with a high antibody response, with many titers $<128 \mathrm{k}$ throughout the period of our study. Each had antibody titers $>128 \mathrm{k}$ in at least 1 bleeding. In our Enzyme Linked Immunosorbont Assay (ELISA), an antibody titer of 32-46k was needed to maintain an infertile state.

\section{Mean Weights}

We obtained weights of the controls and the PZP-treated deer in the autumn (Oct-Nov) and spring (Mar-Apr). Control deer had a mean
Table 1. Serum chemistry concentrations in white-tailed deer immunized with porcine zona pellucida (PZP). Mean \pm standard deviation for control deer $(n=8)$ and treated deer $(n=8)$. Years 1-2 represent years during active immunization and years 3-4 are post immunization. Statistical differences basded on Students' unpaired $t$-test.

\begin{tabular}{|c|c|c|c|c|}
\hline \multirow[b]{2}{*}{ Test $^{a}$} & \multirow[b]{2}{*}{ Units } & \multirow{2}{*}{$\frac{\text { Control deer }}{\text { All years }}$} & \multicolumn{2}{|c|}{ PZP-immunized deer } \\
\hline & & & Years 1-2 & Years 3-4 \\
\hline Alb & $g / d l$ & $2.8 \pm 0.1$ & $2.9 \pm 0.2$ & $3.0 \pm 0.1^{b}$ \\
\hline Alt & $\mathrm{U} / \mathrm{I}$ & $29.2 \pm 7.6$ & $32.4 \pm 8.6$ & $33.7 \pm 8.2^{c}$ \\
\hline AlkP & $\mathrm{U} / \mathrm{I}$ & $86.0 \pm 53.6$ & $69.6 \pm 37.7$ & $66.0 \pm 23.9^{c}$ \\
\hline$A / G$ & & $0.8 \pm 0.1$ & $0.7 \pm 0.1^{b}$ & $0.7 \pm 0.1^{\mathrm{c}, \mathrm{c}}$ \\
\hline Bili & $\mathrm{mg} / \mathrm{dl}$ & $0.5 \pm 0.1$ & $0.8 \pm 0.4^{e}$ & $0.9 \pm 0.3^{b, c}$ \\
\hline Bun & $\mathrm{mg} / \mathrm{dl}$ & $37.7 \pm 7.6$ & $36.3 \pm 7.4$ & $31.0 \pm 8.3^{e, f}$ \\
\hline $\mathrm{Ca}$ & $\mathrm{mg} / \mathrm{dl}$ & $8.4 \pm 1.4$ & $9.1 \pm 0.7^{e}$ & $9.2 \pm 0.5^{9}$ \\
\hline $\mathrm{Cl}$ & meq/l & $101.5 \pm 2.5$ & $101.9 \pm 5.6$ & $103.7 \pm 3.6^{e}$ \\
\hline Chol & $\mathrm{mg} / \mathrm{dl}$ & $72.1 \pm 14.8$ & $68.8 \pm 16.1$ & $64.2 \pm 15.6^{c}$ \\
\hline Crea & $\mathrm{mg} / \mathrm{dl}$ & $1.4 \pm 0.2$ & $1.6 \pm 0.3^{e}$ & $1.7 \pm 0.3^{9}$ \\
\hline GGT & $U / I$ & $64.2 \pm 18.0$ & $84.1 \pm 66.3$ & $73.5 \pm 18.9^{c}$ \\
\hline Glob & $\mathrm{g} / \mathrm{dl}$ & $3.8 \pm 0.5$ & $4.5 \pm 0.6^{b}$ & $4.3 \pm 0.5^{b}$ \\
\hline Glu & $\mathrm{mg} / \mathrm{dl}$ & $260.2 \pm 94.8$ & $258.9 \pm 79.7$ & $330.1 \pm 83.0^{e, h}$ \\
\hline GOT & $\mathrm{U} / \mathrm{I}$ & $84.3 \pm 29.2$ & $108.7 \pm 65.6$ & $111.4 \pm 46.8^{e}$ \\
\hline $\mathrm{Fe}$ & $\mu \mathrm{g} / \mathrm{dl}$ & $208.7 \pm 52.5$ & $200.1 \pm 50.9$ & $198.1 \pm 52.0$ \\
\hline LDH & $U / I$ & $493.6 \pm 163.9$ & $487.3 \pm 191.7$ & $498.7 \pm 142.0$ \\
\hline Phos & $\mathrm{mg} / \mathrm{dl}$ & $6.3 \pm 1.7$ & $5.6 \pm 1.5$ & $5.6 \pm 1.6$ \\
\hline $\mathrm{K}+$ & meq/l & $4.5 \pm 0.5$ & $4.5 \pm 0.6$ & $4.6 \pm 0.6$ \\
\hline $\mathrm{Na}+$ & meq/l & $147.1 \pm 9.7$ & $145.8 \pm 7.1$ & $147.1 \pm 4.1$ \\
\hline Trig & $\mathrm{mg} / \mathrm{dl}$ & $16.8 \pm 10.3$ & $16.1 \pm 11.4$ & $14.7 \pm 9.3$ \\
\hline TP & $\mathrm{g} / \mathrm{dl}$ & $6.6 \pm 0.5$ & $7.3 \pm 0.8^{9}$ & $7.2 \pm 0.8^{\epsilon}$ \\
\hline Uric & $\mathrm{mg} / \mathrm{dl}$ & $0.7 \pm 0.2$ & $0.5 \pm 0.0$ & $0.9 \pm 1.9$ \\
\hline
\end{tabular}

a Abbreviations: Alb $=$ Albumin, Alt $=$ Alanine Aminotransferase, AlkP = Alkaline Phosphatase, A/G = Albumin/Globulin Ratio, Bili = Bilirubin, Bun = Blood Urea Nitrogen, $\mathrm{Ca}=$ Calcium, $\mathrm{Cl}=$ Chloride, $\mathrm{Chol}=$ Cholesterol, Crea $=$ Creatinine, $\mathrm{GGT}$ = Gamma Glutamyl Transferase, Glob = Globulin, Glu = Glucose, $\mathrm{GOT}=$ Glutamic Oxylacetate Transferase, $\mathrm{Fe}=$ Iron, $\mathrm{LDH}=$ Lactate Dehydrogenase, Phos = Phosphate, $\mathrm{K}+=$ Potassium, $\mathrm{Na}+=$ Sodium, Trig $=$ Triglycerides, $\mathrm{TP}=$ Total Protein, Uric = Uric Acid.

b $P<0.0001$ different from untreated.

c $P<0.05$ different from untreated.

d $P<0.05$ different between active and post immunization.

e $P<0.01$ different from untreated.

f $P<0.001$ different between active and post immunization.

$\mathrm{g} P<0.001$ different from untreated.

h $P<0.0001$, other tests $P<0.05$, diffeerent between active and post immunization.

autumn weight of $60.4 \pm 7.3 \mathrm{~kg}$ and a mean spring weight (pregnant) of $67.7 \pm 10.9 \mathrm{~kg}(P<0.05)$. The PZP-treated deer (nonpregnant) had a autumn weight of $64.1 \pm 9.1 \mathrm{~kg}$ and a mean spring weight of $59.6 \pm 8.2(P<0.05)$. No significant dif- 


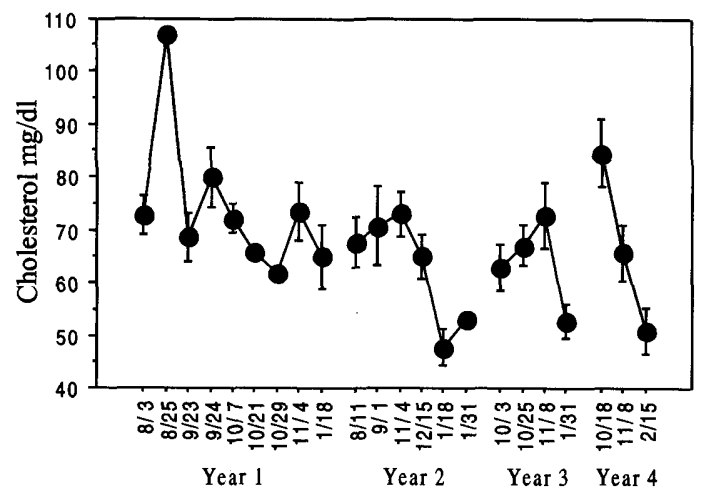

Fig. 1. Serum cholesterol concentrations in white-tailed deer. Mean serum cholesterol values ( \pm SE; $n=16$ ). Autumn levels (Oct-Nov) differed significantly from winter levels (Jan-Feb), $P<0.0001$.

ference existed in weights between treatment groups in the autumn $(P<0.05)$; however, there was a significant difference between treatments in the spring $(P=0.0006)$. The increased weight of the control deer in the spring was probably due to the added weight of the fetus or fetuses. The drop in weight of the PZP (nonpregnant) deer may be due to the stress of the winter. No significant change in weight occurred by either group over the course of the study $(P<0.05)$.

\section{Blood Chemistry Values}

The chemistry data for PZP-treated deer were divided into 2 groups, years 1 and 2 , in which the deer were actively being immunized, and years 3 and 4 , in which the immunocontracepted deer were being monitored for the lasting ability of the anti-PZP antibody titers and the resultant infertility. The 2 years of active immunization may be assumed to be the most stressful or damaging to the reproductive health of the animals. We have previously shown that during active immunization, the deer were not developing progesterone-producing corpora lutea. During the third and fourth years, the deer began to develop normal corpora lutea as indicated by the rise in serum progesterone concentrations.

Of the 22 chemistry parameters that we measured, several parameters showed statistical differences between groups, although none of the values suggested a physiological abnormality. Except for years 3-4, albumin values of the PZPtreated deer were within the normal range as defined by the mean $\pm 2 \mathrm{SD}$ of the values for the control deer. Year 3 of the study included a stressful winter at PSU with over 2 feet of snow in November through December. The increased albumin in the 3-4 year data may represent some resultant dehydration.

\section{Seasonal Chemistry Changes}

Cholesterol was the only parameter for which a seasonal effect was apparent. The seasonal change was observed in both the control and PZP-treated deer. Cholesterol was significantly higher in the autumn (Oct-Nov) bleedings (71.3 $\pm 1.6)$ as compared to the winter (Jan-Feb) bleedings $(51.9 \pm 2.0 ; P<0.0001$; Fig. 1$)$. We found no significant difference in cholesterol changes between the control and treated deer.

\section{DISCUSSION}

Deer show seasonal changes in food intake, activity, and energy expenditure (Plotka et al. 1977, Sauer 1984, Lincoln 1992). Therefore, we compared chemistry values of PZP-treated versus control deer, for the same seasons of the year.

The rise in the concentration of serum cholesterol in the fall may be in preparation for the stress of the winter months, as well as the need for increased synthesis of progesterone and estrogens in preparation for fall breeding, since these sex hormones are synthesized from cholesterol.

The PZP-contracepted deer in our study demonstrated multiple estrous behaviors with breeding activity up to 98 days compared to 44 days for the control deer. This same increased estrous activity was observed by McShea et al. (1997). Their concerns were that the increased breeding activity over an extended period, in a food-limited population, might increase the stress on the herd.

The PSU deer in our study have their nutritional needs met by an abundance of feed, in contrast to free-ranging deer that may be nutritionally deficient. However, in contrast to excessive energy of the multiple estrus as observed for PZP-contracepted deer in the fall, these deer did not have the nutritional demands that are present with pregnant deer in the spring and may actually benefit under conditions of limited food.

In this study, we examined the effect of PZP immunization on the long-term health of deer that have their nutritional demands met. This may or may not relate to a wild population depending on their nutritional status. However, we have shown that the immunization of the deer for contraception has not resulted in deleterious 
health effects. There are indications that contracepted mares are living longer than control pregnant mares (J. Kirkpatrick, ZooMontana, Billings, Montana, USA, personal communication).

\section{MANAGEMENT IMPLICATIONS}

Serum chemistry profiles from this study suggest that the PZP treatment has no major physiological effects on the health of deer, at least in a managed, penned setting. Although this study covered 4 years, a previous paper by Miller et al. (1999), demonstrated that 9 years into the study, 10 out of the 11 deer in the PZP study returned to fertility, generally starting the first year of fertility with a single fawn. The immunocontracepted deer may survive better and live longer under limited food conditions because of the limited demands of the nonpregnant status as compared to pregnant and nursing deer. This study supports the hypothesis that PZP immunocontraception is a safe as well as effective population control method.

\section{LITERATURE CITED}

Dunbar, B. S. 1989. Ovarian antigens and infertility. American Journal of Reproductive Immunology 21:28-31.

KirKPATRICK, J. F., I. K. M. LiU, AND J. W. TuRner. 1990. Remotely-delivered immunocontraception in feral horses. Wildlife Society Bulletin 18:326-330.

- - J. W. Turner, JR., R. NAUgle, AND R. KEIPER. 1992. Long-term effects of porcine zonae pellucidae immunocontraception on ovarian function in feral horses (Equus caballus). Journal of Reproduction and Fertility 94:437-444.

Lincoln, G. A. 1992. Biology of seasonal breeding in deer. Pages 565-574 in R. D. Brown, editor. The biology of deer. Springer-Verlag, New York, USA.

Mahi-Brown, C. A., R. Yanagimachi, M. L. Nelson, H. YanAGIMACHI, AND N. Palumbo. 1988. Ovarian histopathology of bitches immunized with porcine zonae pellucidae. American Journal of Reproductive Immunology and Microbiology 18:94-103.

McShea, W. J., S. L. Monfort, S. Hakim, J. KirkPatrick, I. LiU, J. W. Turner, JR., L. Chassy, AND L. Munson. 1997. The effect of immunocontraception on the behavior and reproduction of white-tailed deer. Journal of Wildlife Management 61:560-569.

Miller, L. A., B. E. JohnS, AND G. J. KILlian. 1999. Longterm effects of PZP immunization on reproduction in white-tailed deer. Vaccine 18:568-574.

$\longrightarrow$, AND $\longrightarrow$ 2000. Immunocontraception of white-tailed deer with GnRH vaccine. American Journal of Reproductive Immunology 44:266-274.

Netrties, V. F. 1997. Potential consequences and problems with wildlife contraceptives. Reproduction, Fertility, and Development 9:137-143.

Plotka, E. D., U. S. Seal, G. C. Schmoller, and P. D. KARNS. 1977. Reproductive steroids in the white-tailed deer (Odocoileus virginianus borealis) I. Seasonal changes in the female. Biology of Reproduction 16:340-343.

SAUER, P. R. 1984. Physical characteristics. Pages 73-90 in L. K. Halls, editor. White-tailed deer: ecology and management. Stackpole Books, Harrisburg, Pennsylvania, USA.

Tumbleson, M. E., M. G. Wood, A. R. Dommert, D. A. MURPHY, AND L. J. KoRSCHGEN. 1968. Biochemic studies on serum from white-tailed deer. American Journal of Veterinary Clinical Pathology 2:121-125.

TUnG, K. S., J. ANG, AND Y. LOU. 1996. ZP3 peptide vaccine that induces antibody and reversible infertility without autoimmune oophoritis. American Journal of Reproductive Immunology 35:181-183.

Turner, J. W., J. F. KIRKPATRICK, AND I. K. M. LiU. 1996. Effectiveness, reversibility, and serum antibody titers associated with immunocontraception in captive white-tailed deer. Journal of Wildlife Management $60: 45-51$

Verne, L. J., AND D. E. Ullrey. 1984. Physiology and nutrition. Pages 91-118 in L. K. Halls, editor. Whitetailed deer: ecology and management. Stackpole Books, Harrisburg, Pennsylvania, USA.

Received 24 October 2000.

Accepted 31 May 2001.

Associate Editor: Rattner. 